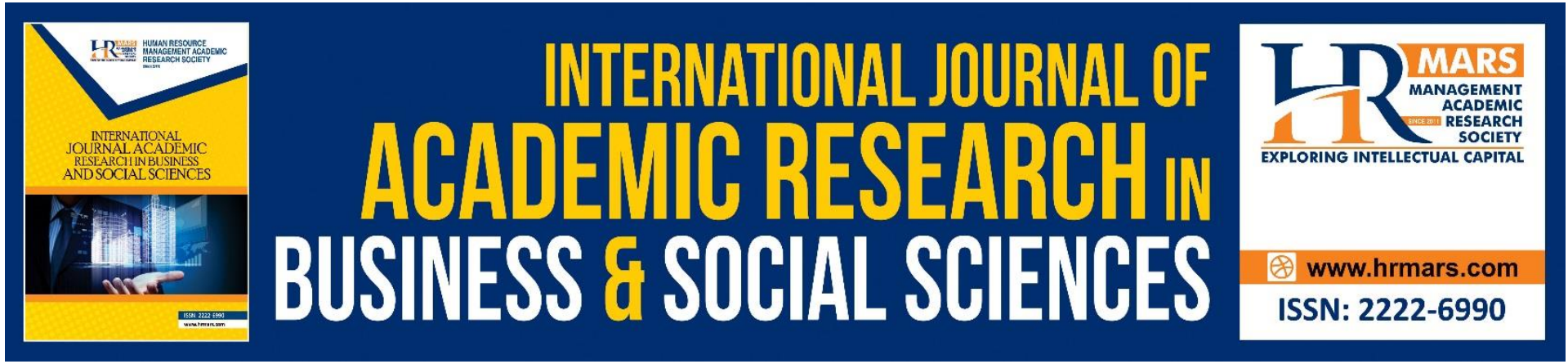

\title{
Improvement of Teaching Portfolio and Course File for Lecturers of the Academy of Contemporary Islamic Studies (ACIS), Universiti Teknologi MARA Penang Branch
}

Emie Sylviana Binti Mohd Zahid, Nurfahiratul Azlina Binti Ahmad

To Link this Article: http://dx.doi.org/10.6007/IJARBSS/v11-i8/10828

DOI:10.6007/IJARBSS/v11-i8/10828

Received: 05 June 2021, Revised: 07 July 2021, Accepted: 25 July 2021

Published Online: 20 August 2021

In-Text Citation: (Zahid \& Ahmad, 2021)

To Cite this Article: Zahid, E. S. B. M., \& Ahmad, N. A. B. (2021). Improvement of Teaching Portfolio and Course File for Lecturers of the Academy of Contemporary Islamic Studies (ACIS), Universiti Teknologi MARA Penang Branch. International Journal Academic Research in Business and Social Sciences, 11(8), 11951206.

Copyright: @ 2021 The Author(s)

Published by Human Resource Management Academic Research Society (www.hrmars.com)

This article is published under the Creative Commons Attribution (CC BY 4.0) license. Anyone may reproduce, distribute, translate and create derivative works of this article (for both commercial and non-commercial purposes), subject to full attribution to the original publication and authors. The full terms of this license may be seen at: http://creativecommons.org/licences/by/4.0/legalcode

Vol. 11, No. 8, 2021, Pg. 1195 - 1206

http://hrmars.com/index.php/pages/detail/IJARBSS

JOURNAL HOMEPAGE

Full Terms \& Conditions of access and use can be found at http://hrmars.com/index.php/pages/detail/publication-ethics 


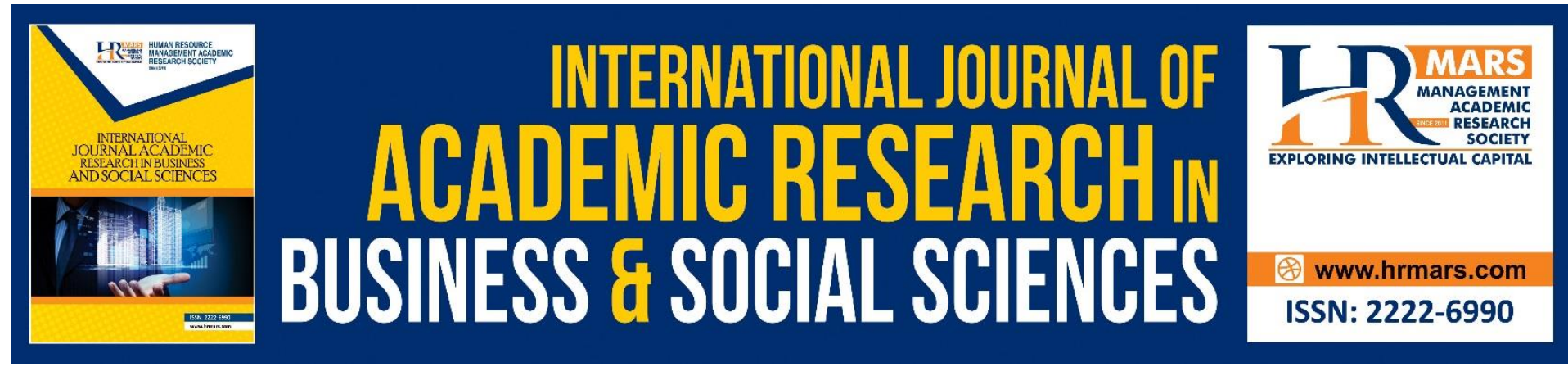

\title{
Improvement of Teaching Portfolio and Course File for Lecturers of the Academy of Contemporary Islamic Studies (ACIS), Universiti Teknologi MARA Penang Branch
}

\author{
Dr Emie Sylviana Binti Mohd Zahid¹, Nurfahiratul Azlina Binti \\ Ahmad $^{2}$ \\ ${ }^{1}$ Academy of Contemporary Islamic Studies (ACIS), Unıversıtı Teknologı MARA, \\ Cawangan Pulau Pinang 13500 Permatang Pauh, Pulau Pinang, Malaysia, ${ }^{2}$ Academy \\ of Contemporary Islamic Studies (ACIS), Unıversıtı Teknologı MARA, Cawangan Pulau \\ Pinang 13500 Permatang Pauh, Pulau Pinang, Malaysia \\ Email: emies692@uitm.edu.my, fahiratul@uitm.edu.my
}

\begin{abstract}
Teaching Portfolio and Course File is an appropriate management tool to control and enhance lecturers' teaching and learning process. Nevertheless, the current documentation holds predicaments concerning time pressure, unintegrated data, low accessibility, and paperbased. The concern of paper wastage regularly happens when teaching materials that are irrelevant need to be discarded. The circumstance, however, contradicts the drive of UiTM moving towards savings. Hence, paper-based documentation needs to be replaced with electronic systems or digital technology. The COVID-19 outbreak has restricted many activities before, and now, it still urgently necessitates a simple, user-friendly app. This research aimed to discuss relevant improvements in providing teaching portfolio documentation and course files by each lecturer of the Academy of Contemporary Islamic Studies (ACIS) at Universiti Teknologi MARA Penang Branch (UiTMCPP). The research method was a descriptive survey study employing a questionnaire. A sum of 10 lecturers was chosen as the sample for the study and represented the ACIS UITMCPP lecturer population. The data obtained were analysed by google form by reporting the number and percentage of respondents' responses. Besides, the ACIS UiTMCPP Quality Unit has taken the initiative by establishing an e-teaching portfolio (e-tp) and e-course file (e-cf) as a facilitation platform for ACIS lecturers. It is proven dynamic from the viewpoint of efficiency, i.e. Firstly, it is timesaving. Most online teaching and learning resources and materials have been uploaded. Therefore, the workflow becomes more streamlined and swift. Secondly, it saves costs. No photocopy costs involved. Thirdly, it boosts productivity. Teaching and learning materials can be shared among lecturers. Next, it is straightforward to use (user friendly). Users interact with the system without the need for advanced skills in the field of computers. Further, it simplifies the auditing process at UiTM.
\end{abstract}


Keywords: Teaching Portfolio, e-TP, Course File, e-CF

\section{Introduction}

A teaching portfolio is a document that comprises a collection of materials utilised in the teaching and learning process of each course taught by each lecturer. It is the personal resource of the lecturer and accessible by the management for the university demands. The teaching portfolio is also an optional document that is compiled and organised, overseeing the professional growth of academics and the achievement of complex endeavours engaged by academics called teaching (Campbell et al., 2001). Preparing a teaching portfolio is imperative and should be performed by all lecturers because this is a methodical outline to document or register all experiences and teaching materials (Peridah Bahari, 2009). It is structured documentation that necessitates meticulous devising, executing and assessing to check creativity, personal progress reports, lists that set work performance standards in organisational planning and implementation (Lateef, 1979). Based on PK.UiTMPP. (O) 07 Course Files and Teaching Portfolios at UiTM, the list of contents of the teaching portfolio that has been set for UiTM lecturers is 'curriculum vitae', course information, teaching and learning materials, assessment, student assignments, results from student examination, lecturer assessment (SuFO) and 'Closing the Loop' (CDL) component analysis. These are the contents that should be stated in the teaching portfolio. 
Table 1: Contents in the Teaching Portfolio

\begin{tabular}{|c|c|}
\hline CONTENTS & DESCRIPTION \\
\hline Curriculum Vitae & $\begin{array}{l}\text { Lecturer information includes personal information, } \\
\text { qualifications, experience, contributions of expertise, } \\
\text { writing and publishing. }\end{array}$ \\
\hline Course Information & $\begin{array}{l}\text { The list contained in the course information includes } \\
\text { the syllabus, course framework, information related to } \\
\text { 'Outcome-Based Education' (OBE) determined by the } \\
\text { faculty such as 'Course Outcomes', 'Program } \\
\text { Outcomes', 'Lesson Outcomes' and Soft Skills (CO- } \\
\text { POLO-KI), 'Course Outcomes', 'Students Learning Time' } \\
\text { (SLT), 'Taxonomy' and 'Lab Grading Rubrics', JSU and } \\
\text { Entrance and Exit Surveys. }\end{array}$ \\
\hline $\begin{array}{l}\text { Teaching and } \\
\text { learning materials } \\
\text { Assessment }\end{array}$ & $\begin{array}{l}\text { The list contained in teaching and learning materials } \\
\text { and reference materials } \\
\text { The list contained in the assessment includes samples } \\
\text { of final examination question papers, tests, quizzes } \\
\text { and working papers. }\end{array}$ \\
\hline Student Assignments & $\begin{array}{l}\text { The list contained in the sample of student } \\
\text { assignments results from student assignments that the } \\
\text { lecturer has reviewed. }\end{array}$ \\
\hline $\begin{array}{l}\text { Student Examination } \\
\text { Results }\end{array}$ & The list contained in the student's examination results \\
\hline Lecturer Assessment. & $\begin{array}{l}\text { The list contained in the lecturer evaluation is the } \\
\text { evaluation of lecturers by students through the } \\
\text { 'Student Feedback Online' (SuFO) system. }\end{array}$ \\
\hline $\begin{array}{ll}\text { 'Closing } & \text { the Loop' } \\
\text { (CDL) } & \text { Component } \\
\text { Analysis } & \end{array}$ & $\begin{array}{l}\text { The list contained in the CDL includes the CDL } \\
\text { 'Outcome Attainment Report', 'Course GPA', 'CO-PO- } \\
\text { LO-KI,' Entrance-Exit Survey (EES), SuFO and 'OBE-SCL } \\
\text { Implementation.' }\end{array}$ \\
\hline
\end{tabular}

The establishment of a teaching portfolio requires updates every semester to support evaluating a lecturer's teaching, promotion and career progression and generally recognising a lecturer's essence. The professional competence of lecturers can also be highlighted and evaluated thoroughly and efficiently (Bahari, 2009). In addition to preparing teaching portfolios, lecturers appointed as course coordinators or Lecturer Incharge (LIC) need to prepare course files as a task entrusted to match the quality system. A course file is a file that contains materials comprising aspects of teaching for as long as the course is offered (https://docplayer.info/187102179-Prosedur-fail-kursus-pk-uitm-fkm-oa-07.html).

At the Academy of Contemporary Islamic Studies (ACIS) UiTM Penang Branch, teaching portfolios and course files are kept in the ACIS Quality Unit. Each semester both documents need updates by each lecturer manually. Nonetheless, there are predicaments encountered by ACIS lecturers when preparing teaching portfolios and course files each year, as in figure 1. 


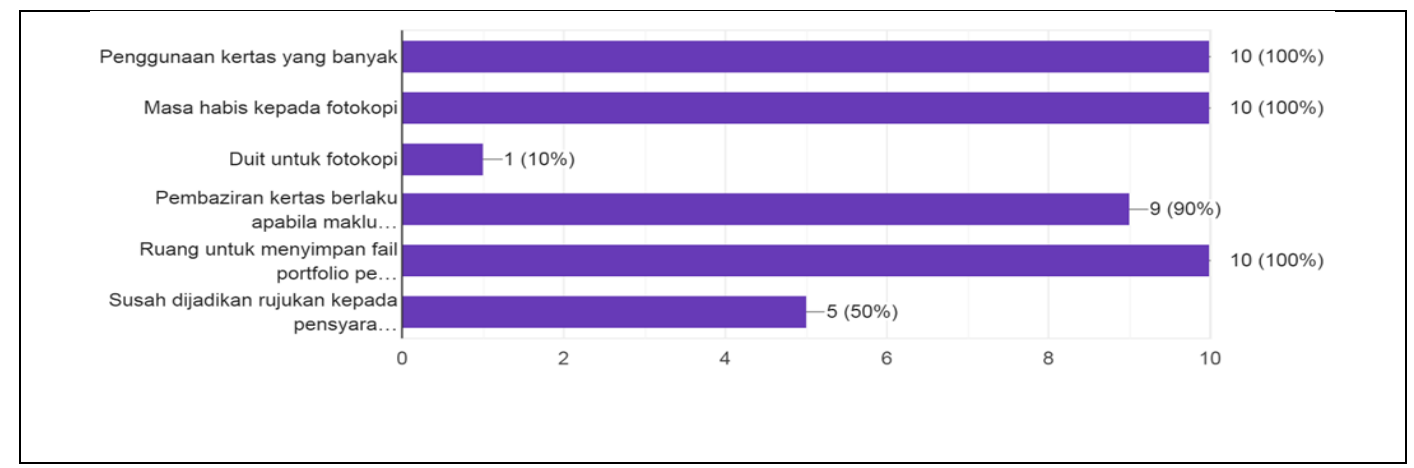

Figure 1: Constraints When Preparing Teaching Portfolios and Course Files

Based on the diagram above, it is evident that the main constraints suffered by the lecturers are the use of excessive paper, time spent on photocopying and the need for space to store portfolio files and course files. The predicament of wastage of paper is also observed by lecturers when they have to discard unrelated documents for storing in the file. It, however, opposes UiTM's current endeavour among its staff towards saving. Thus, suitable improvements as the facilitation of preparing portfolios and course files by each lecturer of the Academy of Contemporary Islamic Studies (ACIS) at Universiti Teknologi MARA Penang Branch (UiTMCPP) is quintessential.

\section{Research Methodology}

The research method chosen was a descriptive survey study using a questionnaire. It was used to obtain feedback from ACIS lecturers when preparing teaching portfolios and course files. This method is proper and easy to get feedback from respondents. This questionnaire contains Part A, and Part B. Part A contains the respondents' background information, namely gender, grade, position, and length of service. In contrast, Part B contains two questions from the lecturer's feedback on preparing the teaching portfolio and course files. Questionnaires were distributed through google form to respondents. The population for this study was the lecturers of the Academy of Contemporary Islamic Studies (ACIS) at UiTM Penang Branch. A sum of 16 ACIS lecturers who served at UiTMPP was elected as the study sample and embodied the population of ACIS lecturers at UiTMPP. The data collected were analysed by google form by stating the number and percentage of respondents' responses to the two questions asked, specifically feedback on the approach introduced and the level of satisfaction with using the approach.

\section{Results}

The research's data resulted from the study's findings collected from the questionnaire that the respondents have filled. The data that has been entered was processed to obtain statistics such as percentage values.

\section{Respondent Demographics}

A total of 10 respondents from 16 ACIS lecturers have answered the questionnaire distributed to get feedback on the teaching portfolio and course files provided by the ACIS Quality Unit, UiTMCPP. The description of the background analysis of the respondents involving aspects of gender, position grade, position and length of service are presented in the form of tables and diagrams. 
Table 2: Female

\begin{tabular}{ccc}
\hline Gender & No. & Percentage (\%) \\
\hline Male & 6 & 60 \\
\hline Female & 4 & 40 \\
\hline & & \\
\hline Jantina \\
10 responses \\
\end{tabular}

Table 2: Female

Based on the table and diagram above, the respondents of this study were $10 \mathrm{ACIS}$ lecturers consisting of six males (60\%) and four females (40\%) of the total respondents.

Table 3: Grade

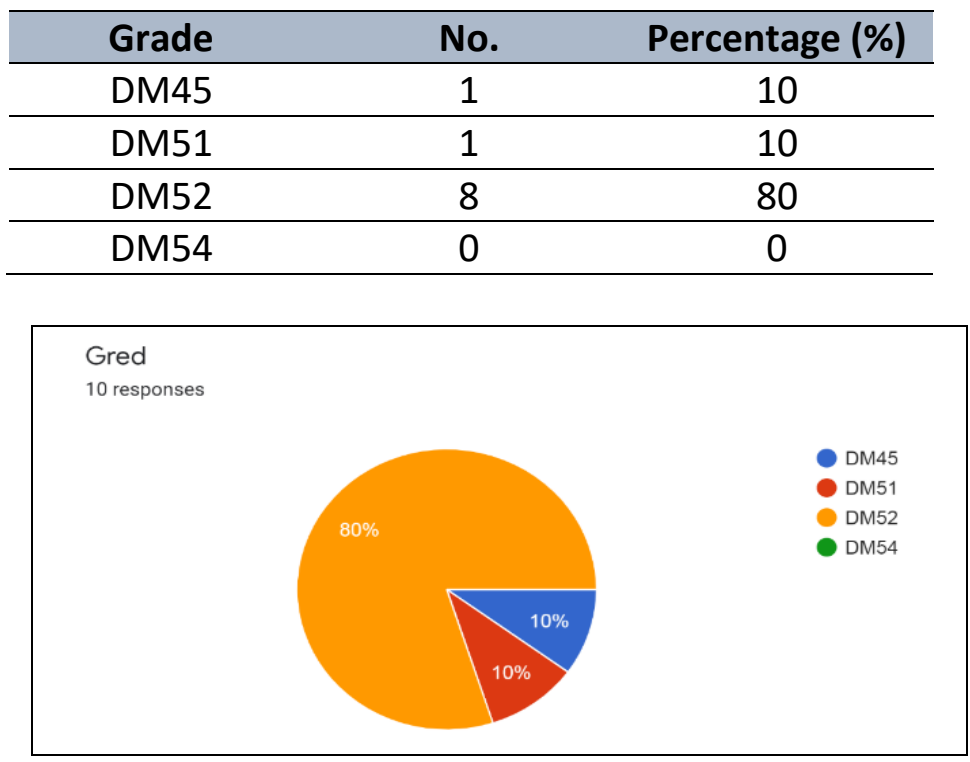

Figure 3: Respondents by Position Grade

The table and diagram above show the number and percentage of respondents based on the position grade among ten respondents of the study. Based on the data obtained, eight of the respondents were DM52 (80\%) grade lecturers, one from DM51 (10\%) and one from DM45 $(10 \%)$. The findings confirmed that the position grade of the respondents consists of various grades. 
Table 4: Positions

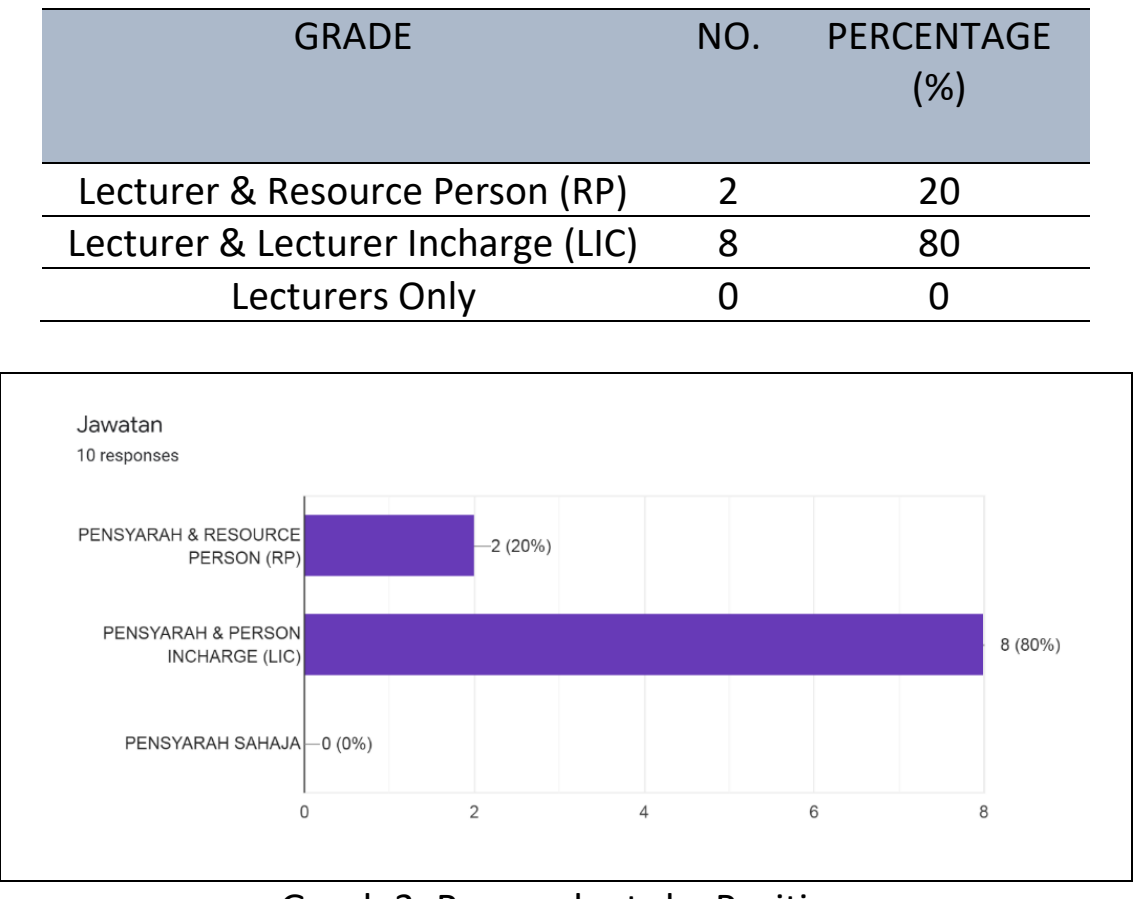

Graph 3: Respondents by Position

The table and graph above show the number and percentage of respondents by position. Based on the data gathered, a total of eight respondents were from the lecturers who held the position of head of course or lecturer in charge (LIC) of (80\%) and two respondents from the lecturers who held the position of resource person (RP) of (20\%). Overall, respondents were individuals who were liable for updating course files and teaching portfolios each semester.

Table 5: Period of Service

\begin{tabular}{ccc}
\hline $\begin{array}{c}\text { PERIOD OF } \\
\text { SERVICE }\end{array}$ & NO. & $\begin{array}{c}\text { PERCENTAGE } \\
(\%)\end{array}$ \\
\hline $1-5$ years & 2 & 20 \\
\hline $6-10$ years & 2 & 20 \\
\hline $11-15$ years & 5 & 50 \\
\hline $\begin{array}{c}16 \text { years and } \\
\text { above }\end{array}$ & 1 & 10 \\
\hline
\end{tabular}

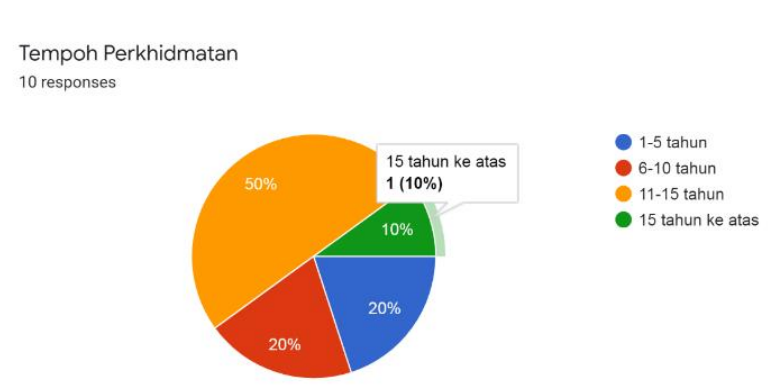

Graph 4: Period of Service

The table and graph above show the number and percentage of respondents by the period of service. Based on the table and graph above, five respondents served for 11 to 15 years $(50 \%)$, 
two respondents served for 1 to 5 years (20\%), two more respondents served for 6 to 10 years, and one served for 16 years above. Overall, the majority of respondents were lecturers who served for 11 to 15 years.

Part B: Feedback on Teaching Portfolio and Course Files Prepared by ACIS Quality Unit, UITMCPP

Adakah anda berpuas hati dengan eTP dan eCF yang dibangunkan oleh Unit Kualiti ACIS? 10 responses

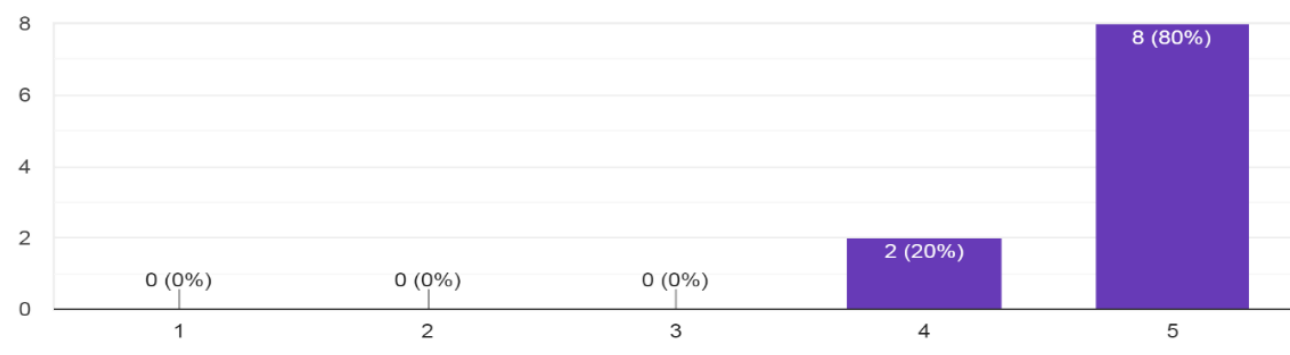

Figure 5: Respondent Satisfaction

Selepas diperkenalkan eTP dan eCF menggunakan platform google drive, apakah pendapat anda sepanjang penggunaannya?

10 responses

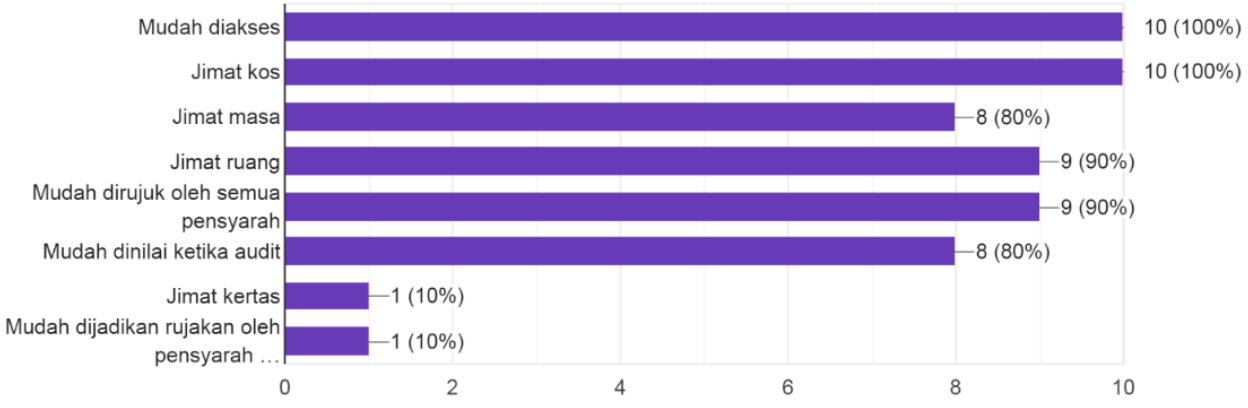

Figure 6: Respondent Feedback

Figure 5 above shows that eight respondents were very satisfied (80\%), and two respondents were satisfied $(20 \%)$ with the platform proposed. Based on figure 6 , respondents were satisfied because eTP and eCF were very accessible by (100\%) and saved the cost of lecturers in preparing documents without the call for photocopying costs of $(100 \%)$. Furthermore, it increased productivity when teaching and learning materials could be shared among lecturers by $(90 \%)$ and easy to use (user-friendly) by $(90 \%)$.

\section{Discussion}

Following the feedback received from ten (100\%) respondents on the chief constraints in the preparation of teaching portfolios and course files, the ACIS UiTMPP Quality Unit has built a platform on Google Drive to facilitate lecturers in preparing documents that include material collection - teaching and learning materials for each course taught. It is crucial because paper- 
based documentation needs replacement with electronic systems. The selection of google drive as a platform because it is in line with the transformation of education and the advancement of information technology, the contribution of Google Drive software can help the educational sphere (Suzana and Fariza, 2014a).

Based on a study attended by Suzana and Fariza (2014b) on Google Drive Software Application As An Alternative To The Online System (OPAC) School Library, it is explicit that the Google Drive application is a program that contains instructions for performing data processing provided by Google Chrome. The researchers chose Google Chrome because it provides Google Drive software containing spreadsheets, forms and directly submits them to the website (Publish to the Web). The researchers utilised the spreadsheet software to download a books database in the library via copy-paste from the offline system data. Additionally, they used form software to build a book loan booking form by students, and all these results will be sent to the website (Publish to the Web), which students can then access through the website address built by the media teacher. This Google Drive model software did not involve a cost. The hardware needed to produce this model involved a computer, LAN (Local Area Network) network coverage and Google Drive software (Suzana and Fariza, 2014b). Google Drive is a storage software provided by Google for its users. It works based on 'Cloud Storage as a Service'. Three platforms can apply google drive, namely Google Drive On The Web, Google Drive On Mobile Device and Google Drive On Computer, where all files can be synchronised to be accessed from any platform (Suzita, 2015). According to Sutiono (2019), the advantages of Google Drive are easy synchronisation, a large amount of memory, can store files in various formats, used as website hosting, share files easily by sharing file links with Google Drive without an email invitation, can be used as a data backup, can run edit files or documents such as Word, Excel and Powerpoint as well as a fairly high-security system. Nevertheless, Google Drive relies massively on the internet network, and data backup on PCs is still not optimal. It is only proficient in the backup photo and video files.

Based on former researches on the Google Drive application and its benefits, the operation of the ACIS Quality Unit followed in executing and standardising the use of e-Teaching Portfolio (e-TP) and e-Course File (e-CF) among ACIS UiTM Penang Branch lecturers after doing the proliferation of the mind by contemplating the pros and cons of the proposal. The following are e-TP and e-CF in Google Drive developed by ACIS Quality Unit, UiTMPP.

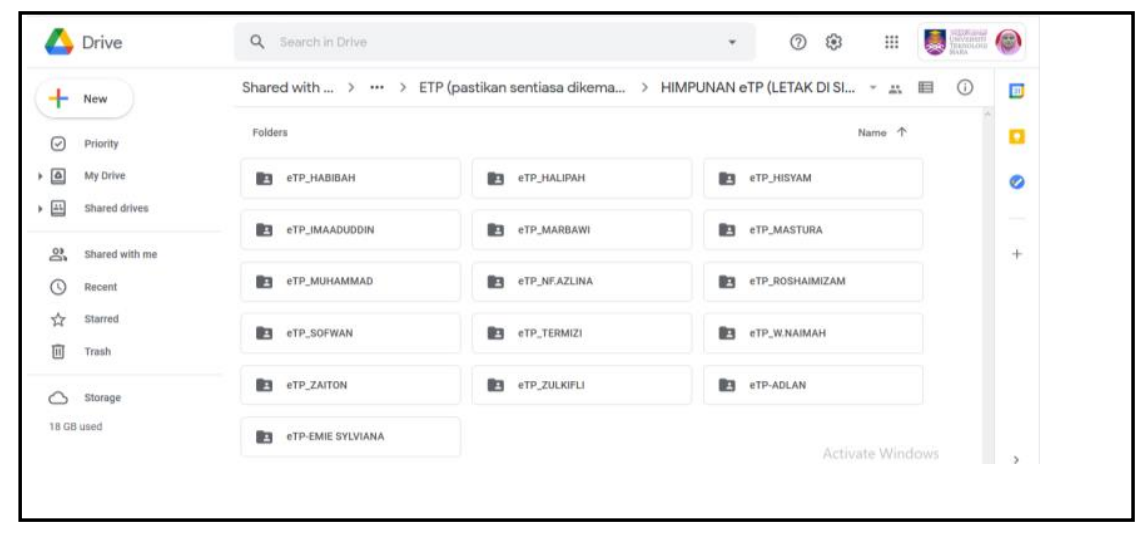

Figure 1: List of e-TP According to ACIS Lecturers 


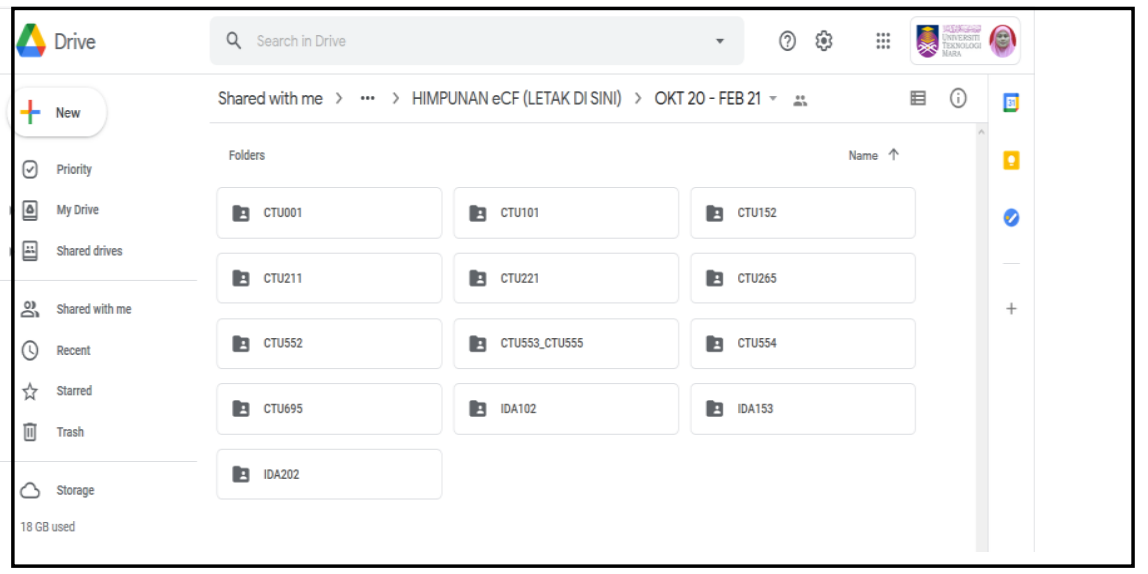

Figure 2: e-CF According to Course Code

The ACIS Quality Unit also provides guidelines for preparing quality files for Online Distance Learning (ODL) teaching and learning throughout the COVID-19 pandemic as a guide for lecturers to utilise the platform. Here are guidelines for preparing quality files.

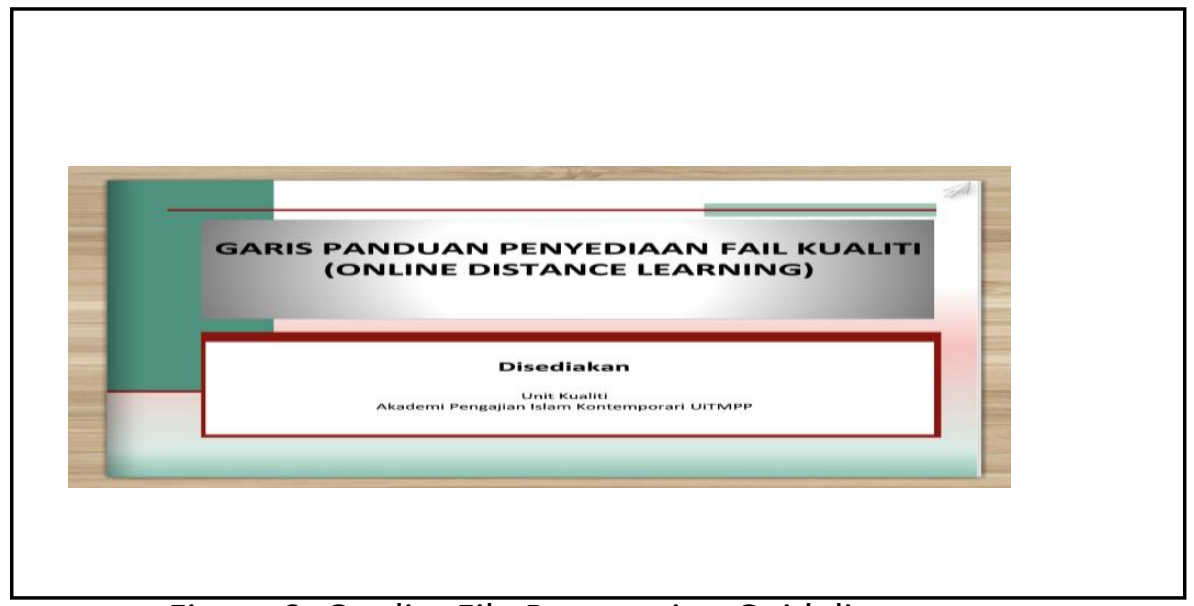

Figure 3: Quality File Preparation Guidelines

The implementation of an e-portfolio or electronic portfolio is a form of a produced portfolio using digital technology either online that is web-based or using media such as optical disc (CD ROM) (Zabri Bin Zainol Abidin, 2011). It is also a collection of artefacts from a personal or organisational collection with a definite goal and stored electronically and operated by an individual or organisation. E-portfolios can also record personal growth and individual learning (Zabri Bin Zainol Abidin, 2011). Thus, e-TP and e-CF are documentation or electronic files of lecturers developed by the ACIS UiTMPP Quality Unit in Google Drive as facilitation to store all learning materials for ACIS lecturers. ACIS lecturers can enjoy using an open-source platform via mobile hardware to upload and store documents in Google Drive during the COVID-19 outbreak. Based on the lecturers' feedback after adopting this approach, ten $(100 \%)$ lecturers confirmed that this approach was readily accessible and cost-effective. It also saved space and easily referred to by other lecturers. $80 \%$ of them were delighted with e-TP and e-CF. 


\section{Conclusion}

The progress of ICT technology, particularly internet technology, has favoured the use of eportfolios. It started to gain a place in the domain of education at the beginning of the 21st century. E-portfolio's establishment intended to display information related to its use in the learning and teaching process. E-portfolio could, too, store past data. These materials could be used as a source of reference for the public. As a result of e-TP and e-CF, $10(100 \%)$ lecturers approved that this approach was easily accessible and cost-effective. It also saved space and easily referred to by other lecturers. $80 \%$ of them were pleased with e-TP and eCF. It profited ACIS lecturers from the aspect of efficiency. First;y, it saved time. Most online teaching and learning resources and materials have been uploaded, so the workflow becomes more efficient and fast. Secondly, it saved costs. No photocopy costs involved. Thirdly, it enhanced productivity. Teaching and learning materials could be shared among lecturers. Next, it eased the use (user friendly) that users interact with the system without the need for exceptional skills in computers. The auditing process by the Quality Unit at UiTM became straightforward by only sharing online access, particularly in the current Covid19 pandemic hit.

Furthermore, the advantage of e-TP is that it facilitated the lecturers to submit teaching materials, research and lecturer activities directly into MyATP and promotion applications. Accordingly, e-TP and e-CF reduced the workload of academics and supported replacing paper-based documentation that fills the ISO room space of the UiTM Quality Unit in each faculty, department and unit with digital or electronic technology systems. The presence of an e-portfolio benefited academics and other parties. Students and corporate companies could also take advantage of its actuality. The advancement of an e-portfolio requires public explanation to maintain its unique aims and aspirations. Ergo, it confirmed that e-portfolios could contribute many interests to human life.

\section{References}

Lateef, N. A. (1979). Pemikiran baru bagi pentadbiran awam Malaysia. Dewan Bahasa dan Pustaka.

Bahari, P. (2009). Peranan Pensyarah dalam Penambahbaikan Kualiti Pengajaran di UiTM Universiti Teknologi MARA (UiTM), Malaysia. Dalam Esteem Academic Journal Vol. 5, No. 2, 231-240, 2009, 231-238.

PK.UiTMPP.(O).07 Fail Kursus Dan PortFolio Pengajaran. https://docplayer.info/187102179-Prosedur-fail-kursus-pk-uitm-fkm-oa-07.html

Sutiono, S., Kom, M., Ko, M. T. I. (2019). 10 Kelebihan dan Kekurangan Google Drive Jarang Diketahui. Diakses pada 1 Jun 2021 dari https://dosenit.com/software/searchengine/google/kelebihan-dan-kekurangan-google-drive

Khalid, S. S. D. F.. (2014a). Pengajaran dan Pembelajaran Menggunakan Perisian Google- Satu Analisis Kajian Lepas. Dalam Pengajaran Sumber dan Teknologi Maklumat: Impaknya ke atas Penyelidikan dalam Pendidikan. Bangi: Penerbit Fakulti Pendidikan, UKM, 2530

Khalid, S. S. D. F. (2014b). Aplikasi Perisian Google Drive Sebagai Alternatif Kepada Sistem Atas Talian (OPAC) Perpustakaan Sekolah. Kertas Kerja. The 4th International Conference on Learner Diversity (ICELD 2014) 383

Suzita. (2015). Google Drive. Diakses pada 1 Jun 2021 dari

http://www.ukm.my/wadahict/google-drive/ 
INTERNATIONAL JOURNAL OF ACADEMIC RESEARCH IN BUSINESS AND SOCIAL SCIENCES

Vol. 11, No. 8, 2021, E-ISSN: 2222-6990 @ 2021 HRMARS

Abidin, Z. B. Z. (2011). E- Portfolio (Learning and Development E-Portfolio). Diakses pada 10 Oktober 2020 dari http://zabrie-portfolioartikel.blogspot.com/2011/12/normal-0false-false-false-en-us-x-none.html 